\title{
Review Article \\ Resveratrol Oligomers for the Prevention and Treatment of Cancers
}

\author{
You-Qiu Xue, ${ }^{1}$ Jin-Ming Di, ${ }^{2}$ Yun Luo, ${ }^{2}$ Ke-Jun Cheng, ${ }^{3}$ Xing Wei, ${ }^{1}$ and Zhi Shi ${ }^{1}$ \\ ${ }^{1}$ Department of Cell Biology \& Institute of Biomedicine, College of Life Science and Technology, Jinan University, \\ Guangzhou, Guangdong 510630, China \\ ${ }^{2}$ Department of Urology, Third Affiliated Hospital of Sun Yat-sen University, Guangzhou, Guangdong 510630, China \\ ${ }^{3}$ Chemical Biology Center, Lishui Institute of Agricultural Sciences, Lishui, Zhejiang 32300, China
}

Correspondence should be addressed to Xing Wei; wei70@hotmail.com and Zhi Shi; tshizhi@jnu.edu.cn

Received 15 January 2014; Accepted 12 February 2014; Published 23 March 2014

Academic Editor: Xiaoqian Chen

Copyright (C) 2014 You-Qiu Xue et al. This is an open access article distributed under the Creative Commons Attribution License, which permits unrestricted use, distribution, and reproduction in any medium, provided the original work is properly cited.

\begin{abstract}
Resveratrol (3,4',5-trihydroxystilbene) is a naturally derived phytoalexin stilbene isolated from grapes and other plants, playing an important role in human health and is well known for its extensive bioactivities, such as antioxidation, anti-inflammatory, anticancer. In addition to resveratrol, scientists also pay attention to resveratrol oligomers, derivatives of resveratrol, which are characterized by the polymerization of two to eight, or even more resveratrol units, and are the largest group of oligomeric stilbenes. Resveratrol oligomers have multiple beneficial properties, of which some are superior in activity, stability, and selectivity compared with resveratrol. The complicated structures and diverse biological activities are of significant interest for drug research and development and may provide promising prospects as cancer preventive and therapeutical agents. This review presents an overview on preventive or anticancer properties of resveratrol oligomers.
\end{abstract}

\section{Introduction}

There are growing interests in using natural compounds as potential cancer therapeutics or cancer preventive agents for human diseases. Lots of epidemiological data illustrate that there is a significant correlation between dietary intake and incidence of many kinds of cancers, and the incidence of cancer trends to raise year by year in the world due to changes in modern lifestyles and diet custom [1-3]. Due to the unsatisfied effectiveness of current cancer chemotherapy, there is an urgent need of new anticancer drugs with high efficiency and low toxicity. Fighting cancers with novel natural products, especially those extracted from plants-derived diet, seems to be a fascinating strategy. Furthermore, in vivo and in vitro studies show that many dietary substances have anticancer properties $[4,5]$. Resveratrol and its oligomers belong to such kind of dietary substances.

Resveratrol $\left(3,4^{\prime}, 5\right.$-trihydroxystilbene) was first isolated from the roots of white hellebore, Veratrum grandiflorum O. Loes [6], found in at least 72 plant species including 12 families and 31 genera [7], and widely exist in edible foods and beverages such as mulberries, peanuts, grapes, and red wine [8]. Resveratrol can be classified either as a polyphenol or stilbene and is produced by plants to protect themselves against damage or infection in response to stresses such as heat, insects, bacteria, and fungus [9]. During the last decade, resveratrol attracted increasing attention due to its preventive potential towards the most severe contemporary human diseases, such as cancer, neurodegenerative disease, vascular disease, cardiovascular disease, and aging [10-13]. Resveratrol was reported to make a great influence on the process of carcinogenesis by affecting cancer initiation and progression $[8,14]$. Resveratrol was shown to exert a different inhibition to various human tumors cells by in vitro experiments through multiple mechanisms as well as different in vivo animal models $[15,16]$. In addition, there was no significant toxicity to mice after the daily oral administration of high doses of resveratrol for 28 days [17].

Chemical structure analysis showed that resveratrol was a polyphenol biphenyl, and multiple hydroxyl groups affected its biological activities as well as cis- or trans-structures [18, 19]. In addition to resveratrol, scientists also focus on its 
Resveratrol<smiles>Oc1ccc(/C=C/c2cc(O)cc(O)c2)cc1</smiles>

Pallidol<smiles>Oc1ccc([C@H]2c3cc(O)cc(O)c3[C@@H](c3ccc(O)cc3)[C@H]2c2ccc(O)cc2)cc1</smiles>

$\mathcal{\varepsilon}$-viniferin<smiles>Oc1ccc(/C=C/c2cc(O)cc3c2C(c2ccc(O)cc2)[C@H](c2ccc(O)cc2)O3)cc1</smiles>

$\mathrm{R}$

Balanocarpol $\alpha-\mathrm{H}$ Ampelopsin $\beta-\mathrm{H}$<smiles>[R2]C(O)c1cc(O)cc2c1C(c1cc(O)cc(O)c1C([R])c1ccc(O)cc1)O[C@H]2c1ccc(O)cc1</smiles>

$\delta$-viniferin<smiles>Oc1ccc(/C=C/c2ccc3c(c2)C(c2ccc(O)cc2)[C@H](c2ccc(O)cc2)O3)cc1</smiles>

Malibatol A<smiles>Oc1ccc(-c2oc3cc(O)cc4c3c2-c2cc(O)cc(O)c2[C@H](O)[C@H]4O)cc1</smiles>

Heimiol A<smiles>Oc1ccc([C@H]2O[C@H](c3ccc(O)cc3)[C@H]3c4cc(O)cc(O)c4[C@H](c4ccc(O)cc4O)[C@H]23)cc1</smiles>

Malibatol B<smiles>Oc1ccc([C@H]2c3c(O)cc(O)c(O)c3-c3c(-c4ccc(O)c(O)c4)oc4cc(O)cc(c34)[C@H]2O)cc1</smiles>

(a)

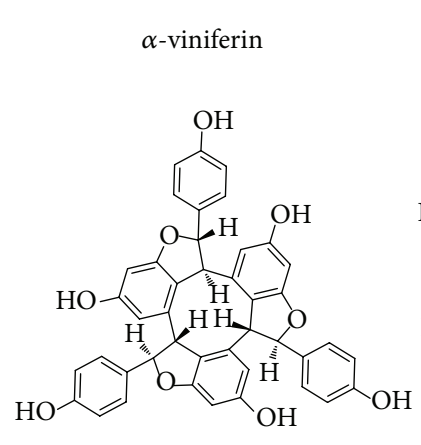

Miyabenol C

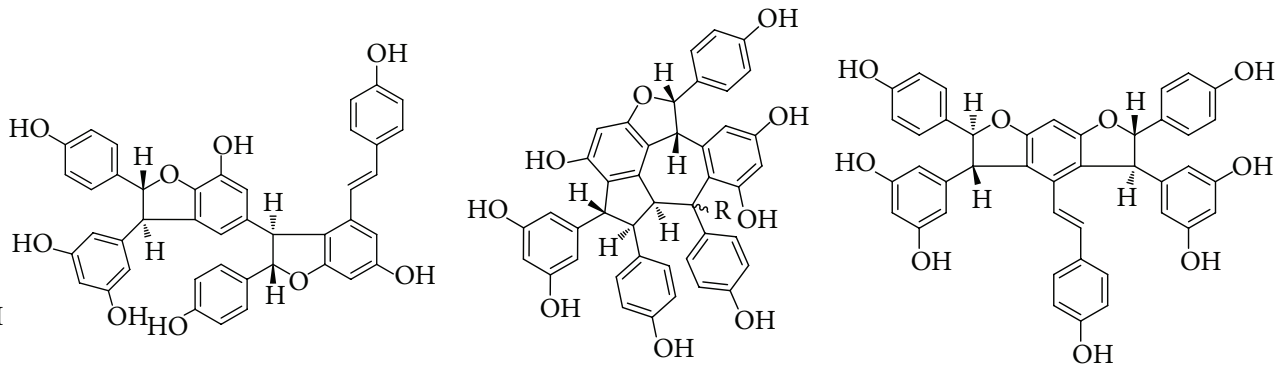

$\mathrm{HO}$

$$
\begin{array}{r}
\mathrm{R} \\
\text { Suffruticosol A } \alpha-\mathrm{H} \\
\text { Suffruticosol B } \beta-\mathrm{H}
\end{array}
$$

Gnetin H

(b)
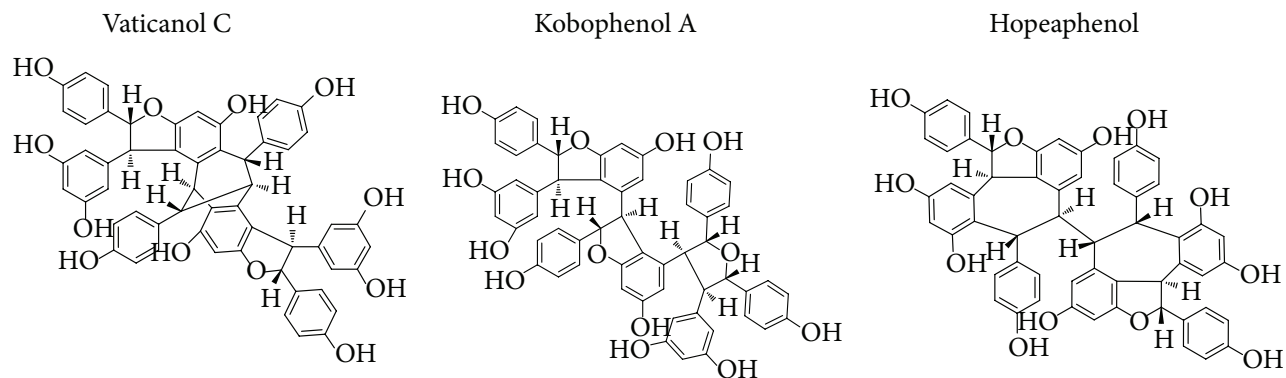

(c)

FIGURE 1: Structure of selected resveratrol oligomers. (a) Resveratrol and resveratrol dimers. (b) Resveratrol trimers. (c) Resveratrol tetramers. 


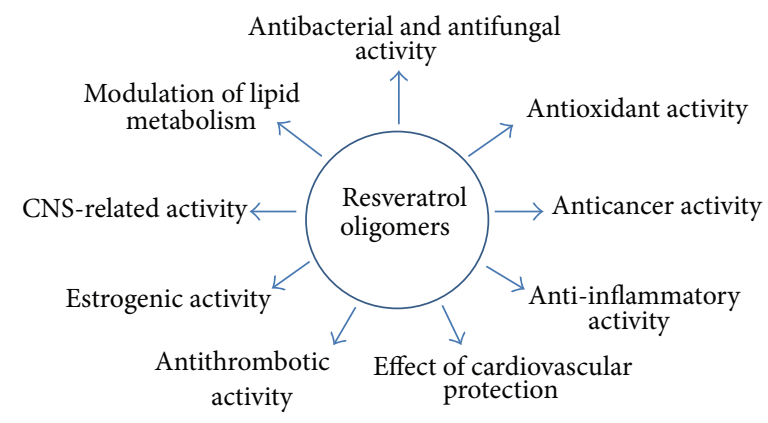

FIGURE 2: Bioactivities of resveratrol oligomers.

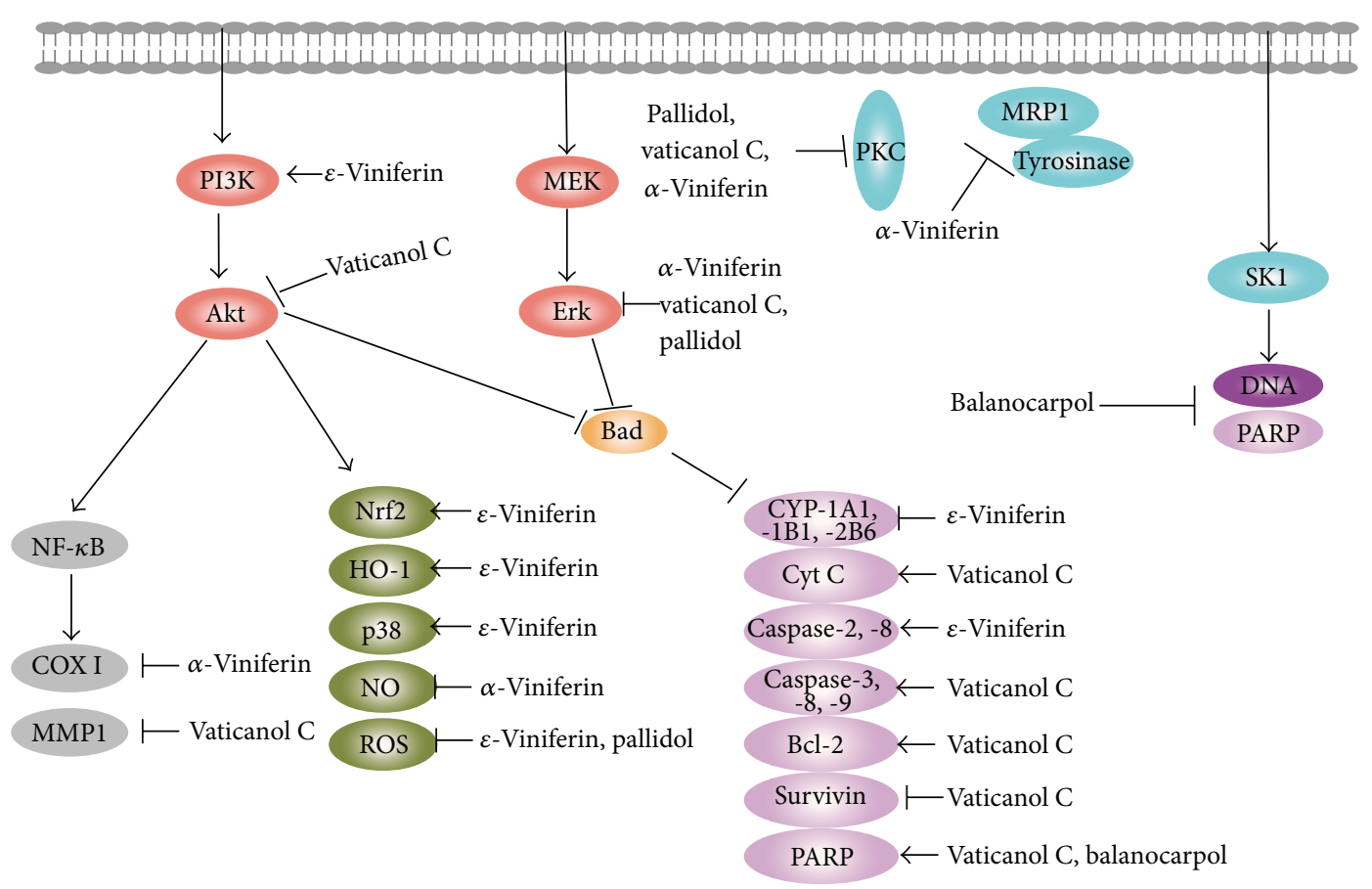

FIGURE 3: The potential molecular mechanism of resveratrol oligomers for the prevention and treatment of cancer.

derivatives, such as resveratrol oligomers. Resveratrol oligomers are characterized by the polymerization of two to eight resveratrol units and even more and are the largest group of oligomeric stilbenes (Figure 1) [20]. Resveratrol oligomers polyphenols were mainly isolated from five plant families, namely, Vitaceae, Leguminosae, Gnetaceae, Dipterocarpaceae, and Cyperaceae [20-23]. In addition, resveratrol oligomers were recognized as fungal detoxification products of resveratrol metabolism. These oligomers were found to exhibit widely biological activities, such as antibacterial, antifungal, anticancer, anti-HIV, and antioxidant activities (Figure 2) $[24,25]$. Their intricate structures and diverse biological activities are of significant interests for drug research and development and may provide promising prospects as cancer preventive and therapeutical agents [26]. Although lots of studies showed various biochemical and pharmacological properties of resveratrol oligomers, so far there is no systematic review about these compounds. In this review, we summarize the recent progresses of the preventive and anticancer activities as well as related mechanisms of resveratrol oligomers (Tables 1 and 2 and Figure 3) and contemplate their prospects as preventive and anticancer agents.

\section{Resveratrol Dimers}

Resveratrol dimers are formed from two resveratrol monomers by oxidation reaction. Series of combination of monomers form different dimers which possess various activities.

2.1. $\varepsilon$-Viniferin. $\varepsilon$-Viniferin, first isolated from Vitis vinifera (Vitaceae), is classified as a model for its biosynthesis from resveratrol [21]. Similar to resveratrol, $\varepsilon$-viniferin also attracted attention as a phytoalexin and was reported to have antifungal, antibacterial, and antiviral activities [59]. To date, many studies of $\varepsilon$-viniferin are about the antioxidant and 
TABLE 1: The anticancer activities of resveratrol oligomers.

\begin{tabular}{|c|c|c|}
\hline $\begin{array}{l}\text { Resveratrol } \\
\text { oligomers }\end{array}$ & Cell lines and inhibition & References \\
\hline \multirow{2}{*}{$\varepsilon$-Viniferin } & $\mathrm{C6}^{+++}, \mathrm{Hep} \mathrm{G} 2^{+}, \mathrm{HeLa}^{++}, \mathrm{MCF}-7^{+}, \mathrm{HT}-29^{+}$ & \multirow{2}{*}{ [27-29] } \\
\hline & $\mathrm{U}^{266^{++}}$, RPMI $8226^{++}$, Jurkat $^{+}, \mathrm{K} 62^{++}, \mathrm{U} 937^{++}$ & \\
\hline Pallidol & $\mathrm{A} 549^{+++}$ & {$[30]$} \\
\hline Balanocarpol & P-388 $8^{++}$ & {$[31,32]$} \\
\hline \multirow{2}{*}{$\alpha$-Viniferin } & HL- $60^{+++}, \mathrm{MCF}^{-} 7^{+}$, Hep G2 ${ }^{+}, \mathrm{A} 549^{+}, \mathrm{P}-388^{+}$, & \multirow{2}{*}[22,33]{} \\
\hline & HCT-116 ${ }^{++}$, HT- $29^{++}$, Caco- $2^{++}$ & \\
\hline \multirow{2}{*}{ Miyabenol C } & $\mathrm{A} 54^{+++}, \mathrm{NCI}-\mathrm{H} 446^{+++}, \mathrm{U} 266^{+++}, \mathrm{RPMI} 8226^{+++}$ & \multirow{2}{*}[22,30,34]{} \\
\hline & Jurkat $^{++}, \mathrm{K}_{562} 2^{+++}, \mathrm{U} 937^{+++}$ & \\
\hline \multirow{2}{*}{ Vaticanol C } & SW- $480^{+++}, \mathrm{DLD}^{-1} 1^{+}$CoLo $201^{+}, \mathrm{PC}-3^{+}, \mathrm{LNCaP}^{++}$ & \multirow{2}{*}[10,35-37]{} \\
\hline & SH-SY5Y ${ }^{++}, \mathrm{HL}_{-} 60^{+++}, \mathrm{K} 62^{+}, \mathrm{U} 937^{++}$ & \\
\hline Kobophenol A & $\mathrm{A} 549^{+}$ & {$[30]$} \\
\hline Hopeaphenol & SW- $480^{+}, \mathrm{HL}-60^{+}, \mathrm{P}-388^{+++}$ & {$[10,28]$} \\
\hline
\end{tabular}

TABLE 2: The potential targets of resveratrol oligomers involved in apoptosis, cell proliferation, and inflammation.

\begin{tabular}{|c|c|c|c|c|}
\hline $\begin{array}{l}\text { Resveratrol } \\
\text { oligomers }\end{array}$ & $\begin{array}{l}\text { Cell cycle } \\
\text { arrest }\end{array}$ & Induction of apoptosis & $\begin{array}{l}\text { Inhibition of proliferation and } \\
\text { inflammation }\end{array}$ & References \\
\hline$\varepsilon$-Viniferin & $\mathrm{G} 2 / \mathrm{M}$ & $\begin{array}{l}\text { ROS } \downarrow \text {, Caspase- } 2,8 \uparrow, \text { CYP1A1 } \downarrow \text {, } \\
\text { CYP1B1 } \downarrow, \text { CYP2B } 6 \downarrow\end{array}$ & $\mathrm{Nrf2} \uparrow, \mathrm{HO}-1 \uparrow, \mathrm{PI} 3 \mathrm{~K} \uparrow, \mathrm{p} 38 \uparrow$ & {$[38-44]$} \\
\hline Pallidol & - & ROS $\downarrow$ & $\mathrm{PKC} \downarrow, \mathrm{ERK} \downarrow$ & {$[45-48]$} \\
\hline Balanocarpol & - & Cleaved PARP $\uparrow$ & $\mathrm{DNA} \downarrow, \mathrm{SK} 1 \downarrow$ & {$[49,50]$} \\
\hline$\alpha$-viniferin & S & - & $\begin{array}{l}\text { PKC } \downarrow \text {, Tyrosinase } \downarrow \text {, MRP } 1 \downarrow \text {, COX I } \downarrow \text {, } \\
\text { NO } \downarrow, \text { STAT } 1 \downarrow, \text { ERK } \downarrow, \text { IFN- } \gamma \downarrow\end{array}$ & {$[45,51-55]$} \\
\hline Miyabenol C & G0/G1 & - & PKC $\downarrow$ & $\begin{array}{c}{[20,22,34,} \\
56]\end{array}$ \\
\hline Vaticanol C & - & 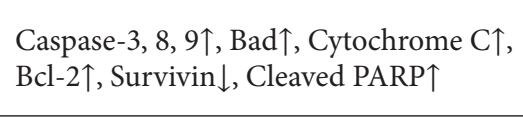 & MEK $\downarrow$, Akt $\downarrow$ & $\begin{array}{c}{[10,26,32} \\
35- \\
37,57,58]\end{array}$ \\
\hline
\end{tabular}

The arrows indicate an increase $(\uparrow)$ or decrease $(\downarrow)$ in the levels, activity of the different signals, or phosphorylation status.

anticancer activities. The antioxidant activity of $\varepsilon$-viniferin is essential in the prevention of oxidative damage or chemicalinduced cancer by inhibiting cancer initiation and progression $[8,60]$. It was reported that $\varepsilon$-viniferin showed the better antioxidant properties to $\mathrm{O}_{2}{ }^{-}$radicals $\left(\mathrm{IC}_{50}\right.$ value of 0.12 to $0.16 \mathrm{mM})$ than resveratrol $\left(\mathrm{IC}_{50}\right.$ value of 0.92 to $0.98 \mathrm{mM}$ ) and could inhibit reactive oxygen species production $[38,61]$. Cytochromes P450 (CYP) are important oxidative enzymes which metabolize xenobiotics including chemical carcinogens. Therefore, one method of cancer prevention is to inhibit carcinogens activation with inhibitors of these phase I enzymes. Modulation of those enzymes has a great influence on toxicity and carcinogenesis. $\varepsilon$-Viniferin displayed a more potent inhibitory effect than resveratrol for CYP enzymes including CYP1A1, CYP1A2, CYP1B1, CYP2A6, CYP2B6, CYP2E1, CYP3A4, and CYP4A (Ki 0.5 to $20 \mu \mathrm{M}$ versus 10 to $100 \mu \mathrm{M}$, resp.), and this effect was not due to an inhibition of the nicotinamide adenine dinucleotide phosphate reductase [39]. $\varepsilon$-Viniferin could also regulate the phase II enzymes to induce carcinogen detoxification. There was a report that $\varepsilon$-viniferin had an inhibitory effect on noradrenaline and 5hydroxytryotamine uptake by synaptosomes from rat brain and on the monoamine oxidase activity [40].

$\varepsilon$-Viniferin also showed the direct cytotoxicity to various cancer cells $[41,42]$. It was reported that $\varepsilon$-viniferin could kill C6, Hep G2, HeLa, and MCF-7 cancer cell lines in a dose-dependent manner with $\mathrm{IC}_{50}$ values of $18.4,74.3,20.4$, and $44.8 \mu \mathrm{g} / \mathrm{mL}$, respectively [43]. In contrast, resveratrol showed stronger cytotoxicity against C6 and Hep G2 with $\mathrm{IC}_{50}$ values of 8.2 and $11.8 \mu \mathrm{g} / \mathrm{mL}$ and weaker cytotoxicity against HeLa and MCF-7 with $\mathrm{IC}_{50}$ values of 20.4 and $44.8 \mu \mathrm{g} / \mathrm{mL}$, respectively [44]. In addition, $\varepsilon$-viniferin showed a potent anticancer activity against allografted sarcoma S180 cells in mice and exerted antiproliferative as well as 
proapoptotic effects on leukemic cells $[27,28,44]$. As for a panel of lymphoid and myeloid cell lines, including U266, RPMI8226, Jurkat, K562 and U937, $\varepsilon$-viniferin, and resveratrol both exert the antiproliferative and proapoptotic effect [28]. Further studies on the multiple myeloma cell line U266 showed that $\varepsilon$-viniferin and resveratrol could regulate cell cycle by affecting different targets [28]. In this model, $\varepsilon$-viniferin induced apoptosis by arresting cell cycle in $\mathrm{G} 2 / \mathrm{M}$, whereas cells treated with resveratrol were accumulated in $S$ phase, and both of them induced apoptosis in a caspasedependent manner by disrupting normal mitochondrial membrance potential $[27,28]$. $\varepsilon$-Viniferin was also able to inhibit Hep G2 cell proliferation by blocking cell cycle at $\mathrm{G} 2 / \mathrm{M}$ phase [60]. In human colon cancer cell lines, $\mathcal{E}$ viniferin was reported to slightly inhibit cells proliferation; however, resveratrol could inhibit cells proliferation and arrest cell cycle at $S$ phase $[62,63]$. Interestingly, the acetylated forms of $\varepsilon$-viniferin and resveratrol possessed more powerful anticancer effects than $\varepsilon$-viniferin and resveratrol [62], and this may pave a new avenue to search new cancer-preventive agents from resveratrol derivative or resveratrol oligomers analogs.

$\delta$-Viniferin, a isomer of $\varepsilon$-viniferin, only exists in plants with a quite low content. There were only few reports about its chemical synthesis, which limited researches on its biological activities. However, $\delta$-viniferin was shown to inhibit the cyclooxygenase- 1 and -2 activities with $\mathrm{IC}_{50}$ values $5 \mu \mathrm{M}[29$, 64].

2.2. Pallidol. Pallidol, first isolated from Cissus pallida, is a natural ingredient of grape present in red wine at a level equal to that in resveratrol [65]. Pallidol was reported to show stronger antioxidant activity than resveratrol [66] and is a potent and selective singlet oxygen quencher in aqueous system. Reactive oxygen species (ROS), including singlet oxygen ${ }^{1} \mathrm{O}_{2}$, superoxide anion $\mathrm{O}_{2}{ }^{--}$, and hydroxyl radical $\cdot \mathrm{OH}$, were reported as being important agents causing aging and various human diseases, such as cancer, autoimmune disease, and Parkinson's disease [67]. Pallidol is a selective ${ }^{1} \mathrm{O}_{2}$ quencher but does not inhibit $\mathrm{O}_{2}{ }^{\cdot-}$ or ${ }^{\circ} \mathrm{OH} .{ }^{1} \mathrm{O}_{2}$ [68] is an excited form of molecular oxygen and usually emerges in photo-sensitized oxidations in biological systems with the ability to react with various targets such as DNA and RNA [69]. Pallidol has a potent ${ }^{1} \mathrm{O}_{2}$ quenching effect at low concentration. Therefore, it may be as a pharmacological agent in singlet oxygen-mediated diseases [68]. Additionally, it was reported that pallidol showed the inhibition of cell growth in a time-dependent manner similar to resveratrol in human colon cancer cells, including HCT-116, HT-29, and Caco-2 cell lines [26]. The peracetylated pallidol possessed strong cytotoxicity against KB, Caki-1, 1A9, MCF-7, and HCT8 cell lines with $\mathrm{IC}_{50}$ values ranging from 1.6 to $8.0 \mu \mathrm{M}$ [45]. Analysis of structure-activity relationship revealed that peracetylated derivatives could increase the anticancer activities of resveratrol oligomers. In addition, pallidol was shown to inhibit protein kinase $\mathrm{C}$ activity [30], suppressed the growth of lung cancer cells A549 [46], and exerted effects on 5hydroxytryptamine 6 receptor-mediated $\mathrm{Ca}^{2+}$ responses and extracellular-signal-regulated kinases (ERK)1/2 phosphorylation as 5-hydroxytryptamine 6 receptor antagonists [70].

2.3. Balanocarpol. Balanocarpol was isolated from two endemic dipterocarp species Balanocarpus zeylanicus (Trimen) and Hopea jucunda (Thw.), and the latter is one of the main genuses of Dipterocarpaceae to produce varieties of resveratrol oligomers such as balanocarpol, heimiol $\mathrm{A}$, and ampelopsin A, H [47, 48, 71]. Balanocarpol and resveratrol were reported as novel sphingosine kinase 1 (SK1) inhibitors by affecting SK1 expression and cancer cells growth and survival [72]. Balanocarpol was a mixed inhibitor (with sphingosine) of SK1 with $K_{\text {ic }}=90 \pm 10 \mu \mathrm{M}$ and $K_{\text {iu }}$ of $\sim 500 \mu \mathrm{M}$, while resveratrol was a competitive inhibitor (with sphingosine) of SK1 with a $K_{\mathrm{ic}}=160 \pm 40 \mu \mathrm{M}$, and both of them could reduce SK1 expression and DNA synthesis and induce poly ADP ribose polymerase (PARP) cleavage in MCF-7 cells [72].

\section{Resveratrol Trimers}

Resveratrol trimers are formed by three resveratrol monomers through head-to-ligation or circular structure, which may lead to their various biological activities. The representative trimers are discussed below.

3.1. $\alpha$-Viniferin. $\alpha$-Viniferin is a stilbene trimer isolated from Caragana sinica, Caragana chamlagu, and the stem bark of Dryobalanops aromatica [31]. It was reported that $\alpha$-viniferin could inhibit the activity of some enzymes, such as protein kinase C (PKC) [30, 73], tyrosinase [49], prostaglandin H-2 synthase [50], and acetylcholinesterase [51]. $\alpha$-Viniferin was shown to have inhibitory effect on PKC with $\mathrm{IC}_{50}$ values of $62.5 \mu \mathrm{M}$ in vitro [30,73]. In addition, $\alpha$-viniferin could inhibit $2^{\prime}, 7^{\prime}$-bis-(carboxypropyl)-5(6)-carboxyfluorescein transport mediated by multidrug resistance protein 1 (MRP1) on the human erythrocyte membrane at low concentration [52]. Compared to resveratrol, $\alpha$-viniferin showed 3- to 4 -fold higher inhibition on cyclooxygenase activity [50]. $\alpha$-Viniferin also showed significant anti-inflammatory activity on carrageenan-induced paw edema in mice through inhibiting cyclooxygenase- 2 effects and nitric oxide synthase [74]. Furthermore, $\alpha$-viniferin powerfully inhibited the signal transducer and activators of transcription 1 (STAT1) inducible inflammatory genes via suppressing ERK-mediated STAT1 activation in interferon- $\gamma$-stimulated macrophages [75].

$\alpha$-Viniferin displayed a striking growth inhibitory effect on various cancer cell lines. It showed marked cytotoxic activity against HL-60 with $\mathrm{IC}_{50}$ values of $2.7 \pm 0.5 \mu \mathrm{M}$ and moderately cytotoxic activity against MCF-7, Hep G2, A549, and murine leukemia P-388 cells [53]. $\alpha$-Viniferin also exerted selective antiproliferative activity against submandibular gland carcinoma but no effects on normal human oral cells such as pulp cells, periodontal ligament fibroblast, and gingival fibroblast [54]. In addition, $\alpha$-viniferin inhibited the proliferation in a concentration- and time-dependent manner by arresting cell cycle at the $S$ phase but not inducing apoptosis of human colon cancer cells in vitro, including HCT-116, HT-29, and Caco-2 cell lines, and was more efficient 
with $\mathrm{IC}_{50}$ values ranging from 6 to $40 \mu \mathrm{M}$ than resveratrol with $\mathrm{IC}_{50}$ values ranging from 120 to $170 \mu \mathrm{M}$ [26]. Together, these studies emphasized the potential of $\alpha$-viniferin for the prevention and treatment of cancer.

3.2. Miyabenol C. Miyabenol C, a stilbenoid and natural resveratrol trimer, was reported to possess lots of biological functions. It revealed that miyabenol $\mathrm{C}$ could inhibit the activity of rat PKC with $\mathrm{IC}_{50}$ values of $27.5 \mu \mathrm{M}$, which is similar to $\varepsilon$-viniferin [19]. In human lung carcinoma cell lines A549 and NCI-H446, miyabenol C showed cytotoxicity with $\mathrm{IC}_{50}$ values of $20 \mu \mathrm{M}$ and induced apoptosis by inhibiting the effects of PKC isoenzymes [46, 55]. Miyabenol C possessed more potent antiproliferative and proapoptotic effects on different lymphoid and myeloid cell lines with $\mathrm{IC}_{50}$ values of 10 to $30 \mu \mathrm{M}$ than resveratrol with $\mathrm{IC}_{50}$ values of 30 to $50 \mu \mathrm{M}$, and cells treated with resveratrol and miyabenol $\mathrm{C}$ were accumulated in S and G0/G1 phase, respectively [28].

\section{Resveratrol Tetramers}

Resveratrol tetramers are formed from four monomers or two different dimers or a monomer and a trimer, and their complex structures lead to different biological activities.

4.1. Vaticanol C. Vaticanol C, isolated from the stem bark of Vatica rassak in Dipterocarpaceae, was reported to exert various pharmacological properties, including antiproliferative, antioxidant, anti-inflammatory, and anticancer properties $[33,34,56,76]$. In a panel of human cancer cell lines, including SW-480, LNCaP, SH-SY5Y, HL-60, and U937, vaticanol $\mathrm{C}$ was able to decrease cell viability and showed 4to 7-fold more potent to induce the death of two cell lines (SW-480 and HL-60) than resveratrol [56]. In another study, the growth of the colon cancer cell lines SW-480, DLD-1, and COLO 201 was significantly inhibited after treated by vaticanol $\mathrm{C}$. The vaticanol $\mathrm{C}$-induced growth inhibition was concentration dependent $[33,56]$. Further studies showed that vaticanol C-induced apoptosis was associated with the decrease of mitochondrial membrane potential, release of cytochrome $\mathrm{c}$ from mitochondria, and activation of caspases3 and -9 and could be prevented by overexpression of Bcl2 [56]. In addition, molecular studies demonstrated that the mechanism of vaticanol C-induced apoptosis was related to the decrease of pErk, pAkt, and pBad [76]. In a mouse model of metastatic mammary carcinoma cells BJMC-3879, the tumor growth was slightly inhibited by vaticanol $\mathrm{C}$, but the multiplicity of metastasis to the lymph nodes and lungs was significantly suppressed due to induced apoptosis with the activation of caspases- $3,-8$, and -9 by ligand- and death-inducing signaling complex-independent pathway [35, 77]. Recently, there was a report that vaticanol $C$ could activate peroxisome proliferators-activated receptor $\alpha / \beta / \delta$, and it suggested that vaticanol $C$ could be a novel agent to afford beneficial effects against lifestyle-related diseases [36]. Vaticanol C also showed significant inhibition of matrix metalloproteinase-1 (MMP-1) production [23].
4.2. Kobophenol A. Kobophenol A, a natural tetramer of resveratrol, could be isolated from Chinese traditional medicine Jin Quegen, the roots of Caragana sinica Rehd, and Caragana chamlagu. It was reported that kobophenol A possessed the ability to inhibit the activity of PKC $[30,73]$ and the growth of lung cancer cell line A549 [46] and showed moderate activity against human colon cancer cell lines [26]. Kobophenol A could inhibit acetylcholinesterase activity and display antimicrobial activity on Staphylococcus aureus [51]. Additionally, kobophenol A showed the characteristics of selective estrogen receptor modulators and it may be as an agent for the prevention of osteoporosis [78].

4.3. Hopeaphenol. Hopeaphenol is a resveratrol tetramer isolated from Dipterocarpaceae like Shorea ovalis and wines from North Africa [57]. Hopeaphenol inhibited the growth of human cancer cells SW-480 and HL-60 [56] and murine leukemia cells P-388 [32]. It possessed potent cytotoxicity against the human epidermoid carcinoma of the nasopharynx [45], hepatoma [42], and also expounded anti-inflammatory [37], antimicrobial [58], and HIV-inhibitory activities [43].

\section{Concluding Remarks}

Resveratrol widely exists in nature and was extensively studied in clinical trials. However resveratrol oligomers were barely studied due to their rare resource and lacking of studying in vivo and in clinical trials. For drug research and design, resveratrol derivatives open a new perspective to selectively develop the health beneficial properties of those natural compounds for the prevention and treatment of human diseases such as cancers. A series of analogs were extracted from different kinds of plants in recent years, which showed more potency for the treatment of human diseases than the parental compound resveratrol. Furthermore, such analogs displayed improved pharmacological properties and various bioactivities, although those results were largely based on experiments with cell cultures or animal studies. There are more and more scientific data to support the use of resveratrol oligomers for human disease prevention or lifespan extension. Resveratrol oligomers target a wide range of molecules that influence cell proliferation, apoptosis, and metastasis. Although the preventive and anticancer mechanism of resveratrol oligomers cannot be limited to a specific pathway, protein, or gene, their use as preventive and anticancer agents has limitless possibilities in its natural and analog forms and should continue to be pursued in future studies.

\section{Conflict of Interests}

The authors declare that there is no conflict of interests regarding the publication of this paper.

\section{Authors' Contribution}

You-Qiu Xue, Jin-Ming Di, and Yun Luo contributed equally to this work. 


\section{Acknowledgments}

This work was supported by funds from the National Natural Science Foundation of China no. 31271444 and no. 81201726 (Z. Shi), no. 30870650 and no. 31171304 (X. Wei), no. 81201694 (Y. Luo), and no. 81303305 (K. Cheng), the Fundamental Research Funds for the Central Universities of Jinan University no. 21612407 (Z. Shi) and no. 21612107 (X. Wei); Research Foundation for Doctoral Discipline of Higher Education no. 20124401120007 (Z. Shi), no. 20114401110007 (X. Wei), and no. 20120171120059 (Y. Luo); and Lishui Science and Technology Bureau Research Fund no. 20140212037 (K. Cheng).

\section{References}

[1] D. W. West, M. L. Slattery, L. M. Robison et al., "Dietary intake and colon cancer: sex- and anatomic site-specific associations," American Journal of Epidemiology, vol. 130, no. 5, pp. 883-894, 1989.

[2] D. W. West, M. L. Slattery, L. M. Robison, T. K. French, and A. W. Mahoney, "Adult dietary intake and prostate cancer risk in Utah: a case-control study with special emphasis on aggressive tumors," Cancer Causes and Control, vol. 2, no. 2, pp. 85-94, 1991.

[3] G. R. Howe, E. Benito, R. Castelleto et al., "Dietary intake of fiber and decreased risk of cancers of the colon and rectum: evidence from the combined analysis of 13 case-control studies," Journal of the National Cancer Institute, vol. 84, no. 24, pp. 18871896, 1992.

[4] M. S. Donaldson, "Nutrition and cancer: a review of the evidence for an anti-cancer diet," Nutrition Journal, vol. 3, article 19, 2004.

[5] P. Fresco, F. Borges, C. Diniz, and M. P. M. Marques, "New insights on the anticancer properties of dietary polyphenols," Medicinal Research Reviews, vol. 26, no. 6, pp. 747-766, 2006.

[6] M. Takaoka, "The phenolic substances of white hellebore (Veratrum Grandiflorum Loes fil.) II," Nippon Kagaku Kaishi, vol. 60, no. 12, pp. 1261-1264, 1939.

[7] K. P. L. Bhat and J. M. Pezzuto, "Cancer chemopreventive activity of resveratrol," Annals of the New York Academy of Sciences, vol. 957, pp. 210-229, 2002.

[8] M. Jang, L. Cai, G. O. Udeani et al., "Cancer chemopreventive activity of resveratrol, a natural product derived from grapes," Science, vol. 275, no. 5297, pp. 218-220, 1997.

[9] J. Burns, T. Yokota, H. Ashihara, M. E. J. Lean, and A. Crozier, "Plant foods and herbal sources of resveratrol," Journal of Agricultural and Food Chemistry, vol. 50, no. 11, pp. 3337-3340, 2002.

[10] K. B. Harikumar and B. B. Aggarwal, "Resveratrol: a multitargeted agent for age-associated chronic diseases," Cell Cycle, vol. 7, no. 8, pp. 1020-1037, 2008.

[11] P. Kovacic and R. Somanathan, "Multifaceted approach to resveratrol bioactivity: focus on antioxidant action, cell signaling and safety," Oxidative Medicine and Cellular Longevity, vol. 3, no. 2, pp. 86-100, 2010.

[12] S. D. Rege, S. Kumar, D. N. Wilson et al., "Resveratrol protects the brain of obese mice from oxidative damage," Oxidative Medicine and Cellular Longevity, vol. 2013, Article ID 419092, 7 pages, 2013

[13] C. D. Venturini, S. Merlo, A. A. Souto, M. D. C. Fernandes, R. Gomez, and C. R. Rhoden, "Resveratrol and red wine function as antioxidants in the nervous system without cellular proliferative effects during experimental diabetes," Oxidative Medicine and Cellular Longevity, vol. 3, no. 6, pp. 434-441, 2010.

[14] Z. Dong, "Molecular mechanism of the chemopreventive effect of resveratrol," Mutation Research, vol. 523-524, pp. 145-150, 2003.

[15] M. Athar, J. H. Back, X. Tang et al., "Resveratrol: a review of preclinical studies for human cancer prevention," Toxicology and Applied Pharmacology, vol. 224, no. 3, pp. 274-283, 2007.

[16] J. A. Baur and D. A. Sinclair, "Therapeutic potential of resveratrol: the in vivo evidence," Nature Reviews Drug Discovery, vol. 5, no. 6, pp. 493-506, 2006.

[17] M. E. Juan, M. Pilar Vinardell, and J. M. Planas, “The daily oral administration of high doses of trans-resveratrol to rats for 28 days is not harmful," Journal of Nutrition, vol. 132, no. 2, pp. 257260, 2002 .

[18] D. Mikulski and M. Molski, "Quantitative structure-antioxidant activity relationship of trans-resveratrol oligomers, trans- $4,4^{\prime}$ dihydroxystilbene dimer, trans-resveratrol-3-O-glucuronide, glucosides: Trans-piceid, cis-piceid, trans-astringin and transresveratrol-4'-O- $\beta$-D-glucopyranoside," European Journal of Medicinal Chemistry, vol. 45, no. 6, pp. 2366-2380, 2010.

[19] R. H. Cichewicz and S. A. Kouzi, "Resveratrol oligomers: structure, chemistry, and biological activity," Studies in Natural Products Chemistry, vol. 26, pp. 507-579, 2002.

[20] A. P. Lins, M. N. D. S. Ribeiro, O. R. Gottlieb, and H. E. Gottlieb, "Gnetins: resveratrol oligomers from Gnetum species," Journal of Natural Products, vol. 45, no. 6, pp. 754-761, 1982.

[21] S. Sotheeswaran and V. Pasupathy, "Distribution of resveratrol oligomers in plants," Phytochemistry, vol. 32, no. 5, pp. 10831092, 1993.

[22] T. Ito, T. Tanaka, M. Iinuma et al., "New resveratrol oligomers in the stem bark of Vatica pauciflora," Tetrahedron, vol. 59, no. 28, pp. 5347-5363, 2003.

[23] N. Abe, T. Ito, K. Ohguchi et al., "Resveratrol oligomers from Vatica albiramis," Journal of Natural Products, vol. 73, no. 9, pp. 1499-1506, 2010.

[24] L. Li, G. E. Henry, and N. P. Seeram, "Identification and bioactivities of resveratrol oligomers and flavonoids from carex folliculata Seeds," Journal of Agricultural and Food Chemistry, vol. 57, no. 16, pp. 7282-7287, 2009.

[25] W. Z. W. M. Zain, N. Ahmat, N. H. Norizan, and N. A. A. M. Nazri, "The evaluation of antioxidant, antibacterial and structural identification activity of trimer resveratrol from Malaysia's dipterocarpaceae," Australian Journal of Basic and Applied Sciences, vol. 5, no. 5, pp. 926-929, 2011.

[26] A. González-Sarrías, S. Gromek, D. Niesen, N. P. Seeram, and G. E. Henry, "Resveratrol oligomers isolated from carex species inhibit growth of human colon tumorigenic cells mediated by cell cycle arrest," Journal of Agricultural and Food Chemistry, vol. 59, no. 16, pp. 8632-8638, 2011.

[27] C. Quiney, C. Billard, A. M. Faussat et al., "Pro-apoptotic properties of hyperforin in leukemic cells from patients with Bcell chronic lymphocytic leukemia," Leukemia, vol. 20, no. 3, pp. 491-497, 2006.

[28] C. Barjot, M. Tournaire, C. Castagnino, C. Vigor, J. Vercauteren, and J.-F. Rossi, "Evaluation of antitumor effects of two vine stalk oligomers of resveratrol on a panel of lymphoid and myeloid cell lines: comparison with resveratrol," Life Sciences, vol. 81, no. 2324, pp. 1565-1574, 2007. 
[29] X. Vitrac, A. Bornet, R. Vanderlinde et al., "Determination of stilbenes ( $\delta$-viniferin, trans-astringin, trans-piceid, cis- and trans-resveratrol, $\varepsilon$-viniferin) in Brazilian wines," Journal of Agricultural and Food Chemistry, vol. 53, no. 14, pp. 5664-5669, 2005.

[30] G. Xu, L. P. Zhang, L. F. Chen, and C. Q. Hu, "Inhibition of protein kinase C by stilbenoids," Acta Pharmaceutica Sinica, vol. 29, no. 11, pp. 818-822, 1994.

[31] T. Shen, X.-N. Wang, and H.-X. Lou, "Natural stilbenes: an overview," Natural Product Reports, vol. 26, no. 7, pp. 916-935, 2009.

[32] M. Muhtadi, E. H. Hakim, L. D. Juliawaty et al., "Cytotoxic resveratrol oligomers from the tree bark of Dipterocarpus hasseltii," Fitoterapia, vol. 77, no. 7-8, pp. 550-555, 2006.

[33] T. Ito, Y. Akao, T. Tanaka, M. Iinuma, and Y. Nozawa, "Vaticanol $\mathrm{C}$, a novel resveratrol tetramer, inhibits cell growth through induction of apoptosis in colon cancer cell lines," Biological \& pharmaceutical bulletin, vol. 25, no. 1, pp. 147-148, 2002.

[34] T. A. Zykova, F. Zhu, X. Zhai et al., "Resveratrol directly targets COX-2 to inhibit carcinogenesis," Molecular Carcinogenesis, vol. 47, no. 10, pp. 797-805, 2008.

[35] M.-A. Shibata, Y. Akao, E. Shibata et al., "Vaticanol C, a novel resveratrol tetramer, reduces lymph node and lung metastases of mouse mammary carcinoma carrying p 53 mutation," Cancer Chemotherapy and Pharmacology, vol. 60, no. 5, pp. 681-691, 2007.

[36] T. Tsukamoto, R. Nakata, E. Tamura et al., "Vaticanol C, a resveratrol tetramer, activates $\mathrm{PPAR}$ and $\operatorname{PPAR} \beta / \delta$ in vitro and in vivo," Nutrition and Metabolism, vol. 7, article 46, 2010.

[37] K.-S. Huang, M. Lin, and G.-F. Cheng, "Anti-inflammatory tetramers of resveratrol from the roots of Vitis amurensis and the conformations of the seven-membered ring in some oligostilbenes," Phytochemistry, vol. 58, no. 2, pp. 357-362, 2001.

[38] C. Privat, J. P. Telo, V. Bernardes-Genisson, A. Vieira, J.-P. Souchard, and F. Nepveu, "Antioxidant properties of trans-EViniferin as compared to stilbene derivatives in aqueous and nonaqueous media," Journal of Agricultural and Food Chemistry, vol. 50, no. 5, pp. 1213-1217, 2002.

[39] B. Piver, F. Berthou, Y. Dreano, and D. Lucas, "Differential inhibition of human cytochrome P450 enzymes by $\varepsilon$-viniferin, the dimer of resveratrol: comparison with resveratrol and polyphenols from alcoholized beverages," Life Sciences, vol. 73, no. 9, pp. 1199-1213, 2003.

[40] M. Yáñez, N. Fraiz, E. Cano, and F. Orallo, “(-)-Trans- $\varepsilon-$ viniferin, a polyphenol present in wines, is an inhibitor of noradrenaline and 5-hydroxytryptamine uptake and of monoamine oxidase activity," European Journal of Pharmacology, vol. 542, no. 1-3, pp. 54-60, 2006.

[41] J. K. Hyo, J. C. Eun, J. B. Song et al., "Cytotoxic and antimutagenic stilbenes from seeds of Paeonia lactiflora," Archives of Pharmacal Research, vol. 25, no. 3, pp. 293-299, 2002.

[42] S. Rohaiza, W. A. Yaacob, L. B. Din, and I. Nazlina, "Cytotoxic oligostilbenes from shorea hopeifolia," African Journal of Pharmacy and Pharmacology, vol. 5, no. 10, pp. 1272-1277, 2011.

[43] S. Mishima, K. Matsumoto, Y. Futamura et al., "Antitumor effect of stilbenoids from Vateria indica against allografted sarcoma S180 in animal model," Journal of Experimental Therapeutics and Oncology, vol. 3, no. 5, pp. 283-288, 2003.

[44] C. Quiney, D. Dauzonne, C. Kern et al., "Flavones and polyphenols inhibit the NO pathway during apoptosis of leukemia Bcells," Leukemia Research, vol. 28, no. 8, pp. 851-861, 2004.
[45] M. Ohyama, T. Tanaka, T. Ito, M. Iinuma, K. F. Bastow, and K.-H. Lee, "Antitumor agents 200. Cytotoxicity of naturally occurring resveratrol oligomers and their acetate derivatives," Bioorganic and Medicinal Chemistry Letters, vol. 9, no. 20, pp. 3057-3060, 1999.

[46] S. Zhi and X. Guang, "Growth inhibitory effect of stilbenoids on lung cancer lines," Acta Academiae Medicinae Sinicae, vol. 25, pp. 327-330, 1998.

[47] S. Atun, R. A. Nurfina, and M. Niwa, "Balanocarpol and Heimiol A, two resveratrol dimers from stem bark Hopea mengarawan (Dipterocarpaceae), Indo," Indonesian Journal of Chemistry, vol. 6, no. 1, pp. 75-78, 2006.

[48] S. Atun, R. A. Nurfina, and M. Niwa, "Balanocarpol and ampelopsin $\mathrm{H}$, two resveratrol dimers from stem bark Hopea mengarawan (Dipterocarpaceae)," Indonesian Journal of Chemistry, vol. 6, no. 3, pp. 307-311, 2006.

[49] K. Ohguchi, T. Tanaka, T. Ito et al., "Inhibitory effects of resveratrol derivatives from dipterocarpaceae plants on tyrosinase activity," Bioscience, Biotechnology and Biochemistry, vol. 67, no. 7, pp. 1587-1589, 2003.

[50] S.-H. Lee, N.-H. Shin, S.-H. Kang et al., " $\alpha$-Viniferin: a prostaglandin $\mathrm{H} 2$ synthase inhibitor from root of Carex humilis," Planta Medica, vol. 64, no. 3, pp. 204-207, 1998.

[51] S. H. Sung, S. Y. Kang, K. Y. Lee et al., “(+)-Alpha-viniferin, a stilbene trimer from Caragana chamlague, inhibits acetylcholinesterase," Biological \& pharmaceutical bulletin, vol. 25, no. 1, pp. 125-127, 2002.

[52] M. Bobrowska-Hägerstrand, M. Lillås, L. Mrówczyñska et al., "Resveratrol oligomers are potent MRP1 transport inhibitors," Anticancer Research, vol. 26, no. 3 A, pp. 2081-2084, 2006.

[53] A. Wibowo, N. Ahmat, A. S. Hamzah et al., "Malaysianol A, a new trimer resveratrol oligomer from the stem bark of Dryobalanops aromatica," Fitoterapia, vol. 82, no. 4, pp. 676681, 2011.

[54] S. A. Chowdhury, K. Kishino, R. Satoh et al., "Tumor-specificity and apoptosis-inducing activity of stilbenes and flavonoids," Anticancer Research, vol. 25, no. 3 B, pp. 2055-2063, 2005.

[55] S. Zhi, T. Chunyan, W. Yuxiong, H. Hong, and X. Guang, "Effects of miyabenol-C on protein kinase-C in two lung carcinoma cell lines," Chinese Medical Journal, vol. 6, p. 001, 1999.

[56] T. Ito, Y. Akao, H. Yi et al., "Antitumor effect of resveratrol oligomers against human cancer cell lines and the molecular mechanism of apoptosis induced by vaticanol C," Carcinogenesis, vol. 24, no. 9, pp. 1489-1497, 2003.

[57] H. A. Guebailia, K. Chira, T. Richard et al., "Hopeaphenol: the first resveratrol tetramer in wines from North Africa," Journal of Agricultural and Food Chemistry, vol. 54, no. 25, pp. 9559-9564, 2006.

[58] J. R. Zgoda-Pols, A. J. Freyer, L. B. Killmer, and J. R. Porter, "Antimicrobial resveratrol tetramers from the stem bark of Vatica oblongifolia ssp. oblongifolia," Journal of Natural Products, vol. 65, no. 11, pp. 1554-1559, 2002.

[59] A. E. A. Bala, A. Kollmann, P.-H. Ducrot et al., "Cis $\varepsilon$-viniferin: a new antifungal resveratrol dehydrodimer from Cyphostemma crotalarioides roots," Journal of Phytopathology, vol. 148, no. 1, pp. 29-32, 2000.

[60] D. Colin, A. Lancon, D. Delmas et al., "Antiproliferative activities of resveratrol and related compounds in human hepatocyte derived HepG2 cells are associated with biochemical cell disturbance revealed by fluorescence analyses," Biochimie, vol. 90, no. 11-12, pp. 1674-1684, 2008. 
[61] H. J. Kim, E. J. Chang, S. H. Cho, S. K. Chung, H. D. Park, and S. W. Choi, "Antioxidative activity of resveratrol and its derivatives isolated from seeds of Paeonia lactiflora," Bioscience, Biotechnology and Biochemistry, vol. 66, no. 9, pp. 1990-1993, 2002.

[62] D. Colin, A. Gimazane, G. Lizard et al., "Effects of resveratrol analogs on cell cycle progression, cell cycle associated proteins and 5fluoro-uracil sensitivity in human derived colon cancer cells," International Journal of Cancer, vol. 124, no. 12, pp. 2780 2788, 2009.

[63] A.-K. Marel, G. Lizard, J.-C. Izard, N. Latruffe, and D. Delmas, "Inhibitory effects of trans-resveratrol analogs molecules on the proliferation and the cell cycle progression of human colon tumoral cells," Molecular Nutrition and Food Research, vol. 52, no. 5, pp. 538-548, 2008.

[64] V. Vingtdeux, U. Dreses-Werringloer, H. Zhao, P. Davies, and P. Marambaud, "Therapeutic potential of resveratrol in Alzheimer's disease," BMC Neuroscience, vol. 9, no. supplement 2, p. S6, 2008.

[65] M. A. Khan, S. G. Nabi, S. Prakash, and A. Zaman, "Pallidol, a resveratrol dimer from Cissus pallida," Phytochemistry, vol. 25, no. 8, pp. 1945-1948, 1986.

[66] H. J. Kim, M. Saleem, S. H. Seo, C. Jin, and Y. S. Lee, "Two new antioxidant stilbene dimers, parthenostilbenins A and B from Parthenocissus tricuspidata," Planta Medica, vol. 71, no. 10, pp. 973-976, 2005.

[67] J. L. Marx, "Oxygen free radicals linked to many diseases," Science, vol. 235, no. 4788, pp. 529-531, 1987.

[68] S. He, L. Jiang, B. Wu, Y. Pan, and C. Sun, "Pallidol, a resveratrol dimer from red wine, is a selective singlet oxygen quencher," Biochemical and Biophysical Research Communications, vol. 379, no. 2, pp. 283-287, 2009.

[69] T. Hofer, C. Badouard, E. Bajak, J.-L. Ravanat, Å. Mattsson, and I. A. Cotgreave, "Hydrogen peroxide causes greater oxidation in cellular RNA than in DNA," Biological Chemistry, vol. 386, no. 4, pp. 333-337, 2005.

[70] D. H. Kim, S.-H. Kim, H. J. Kim, C. Jin, K. C. Chung, and H. Rhim, "Stilbene derivatives as human 5-HT6 receptor antagonists from the root of Caragana sinica," Biological and Pharmaceutical Bulletin, vol. 33, no. 12, pp. 2024-2028, 2010.

[71] S. Sahidin, E. H. Hakim, L. D. Juliawaty et al., "Cytotoxic properties of oligostilbenoids from the tree barks of Hopea dryobalanoides," Zeitschrift fur Naturforschung C Journal of Biosciences, vol. 60, no. 9-10, pp. 723-727, 2005.

[72] K. G. Lim, A. I. Gray, S. Pyne, and N. J. Pyne, "Resveratrol dimers are novel sphingosine kinase 1 inhibitors and affect sphingosine kinase 1 expression and cancer cell growth and survival," British Journal of Pharmacology, vol. 166, no. 5, pp. 1605-1616, 2012.

[73] P. Kulanthaivel, W. P. Janzen, L. M. Ballas et al., "Naturally occurring protein kinase $\mathrm{C}$ inhibitors; II. Isolation of oligomeric stilbenes from Caragana sinica," Planta Medica, vol. 61, no. 1, pp. 41-44, 1995.

[74] E. Y. Chung, B. H. Kim, M. K. Lee et al., "Anti-inflammatory effect of the oligomeric stilbene $\alpha$-viniferin and its mode of the action through inhibition of cyclooxygenase- 2 and inducible nitric oxide synthase," Planta Medica, vol. 69, no. 8, pp. 710-714, 2003.

[75] E. Y. Chung, E. Roh, J.-A. Kwak et al., " $\alpha$-Viniferin suppresses the signal transducer and activation of transcription-1 (stat1)-inducible inflammatory genes in interferon- $\gamma$-stimulated macrophages," Journal of Pharmacological Sciences, vol. 112, no. 4, pp. 405-414, 2010.

[76] K. Ohguchi, Y. Akao, K. Matsumoto et al., "Vaticanol C-induced cell death is associated with inhibition of pro-survival signaling in HL60 human leukemia cell line," Bioscience, Biotechnology and Biochemistry, vol. 69, no. 2, pp. 353-356, 2005.

[77] D. A. Martin, R. M. Siegel, L. Zheng, and M. J. Lenardo, "Membrane oligomerization and cleavage activates the caspase8 (FLICE/MACH $\alpha 1$ ) death signal," The Journal of Biological Chemistry, vol. 273, no. 8, pp. 4345-4349, 1998.

[78] C.-Y. Tian, C.-Q. Hu, G. Xu, and H.-Y. Song, "Assessment of estrogenic activity of natural compounds using improved Escreen assay," Acta Pharmacologica Sinica, vol. 23, no. 6, pp. 572576, 2002. 


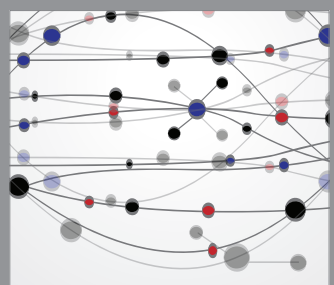

The Scientific World Journal
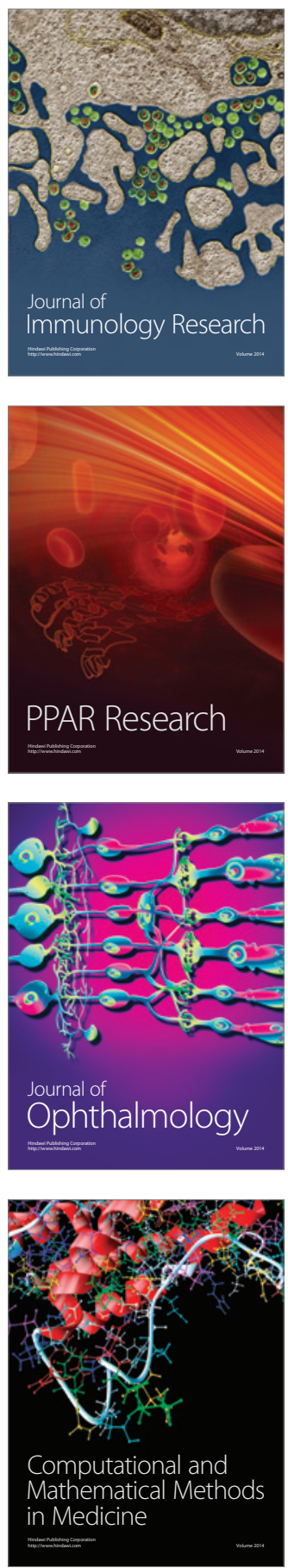

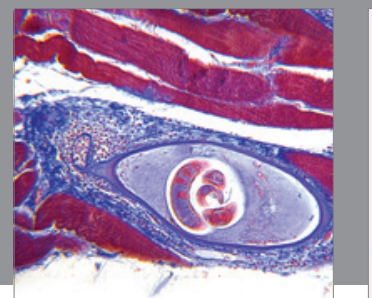

Gastroenterology

Research and Practice
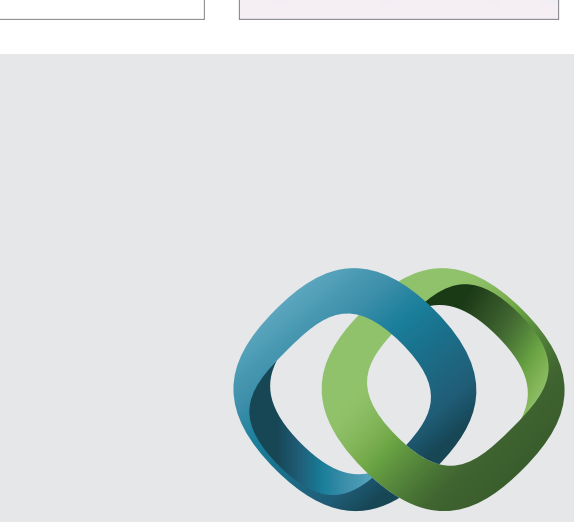

\section{Hindawi}

Submit your manuscripts at

http://www.hindawi.com
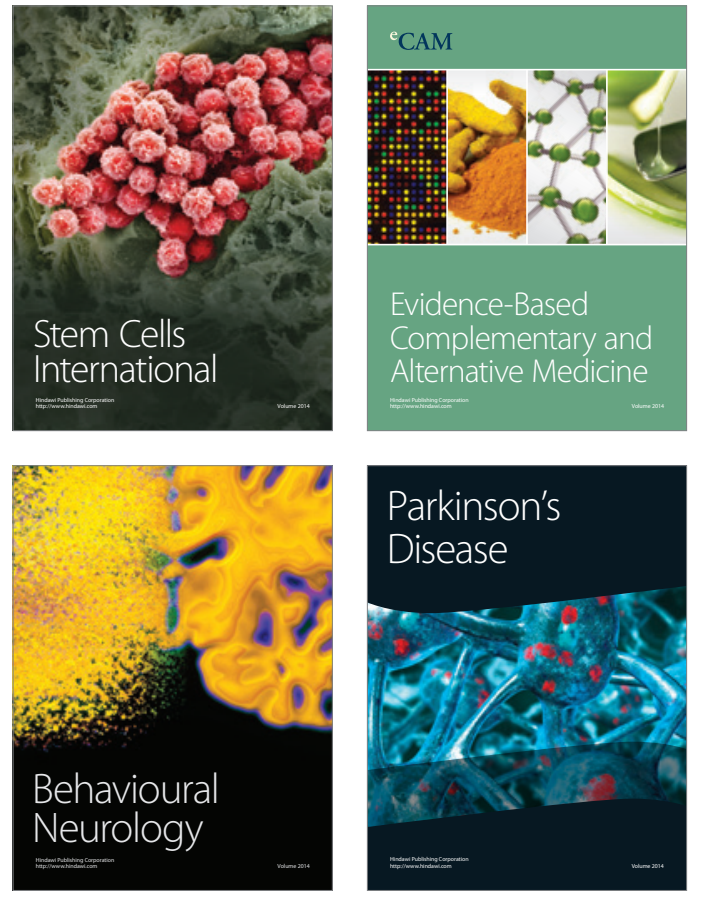
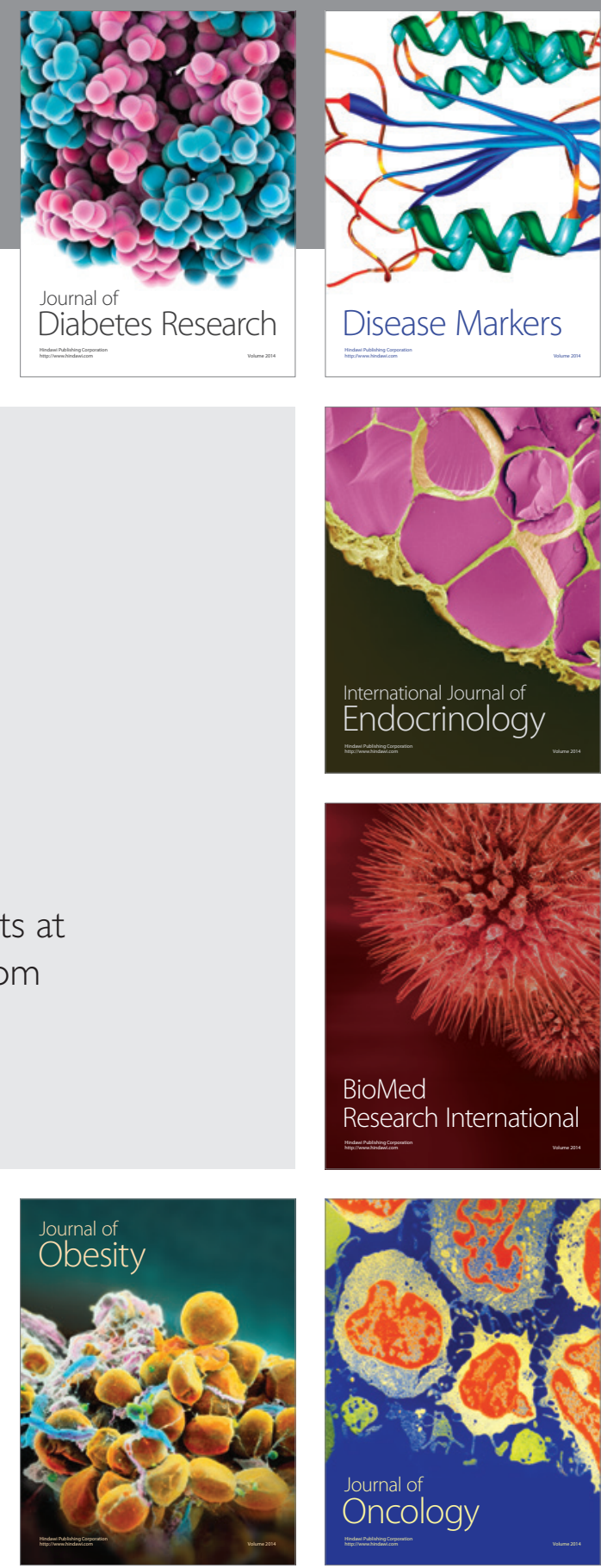

Disease Markers
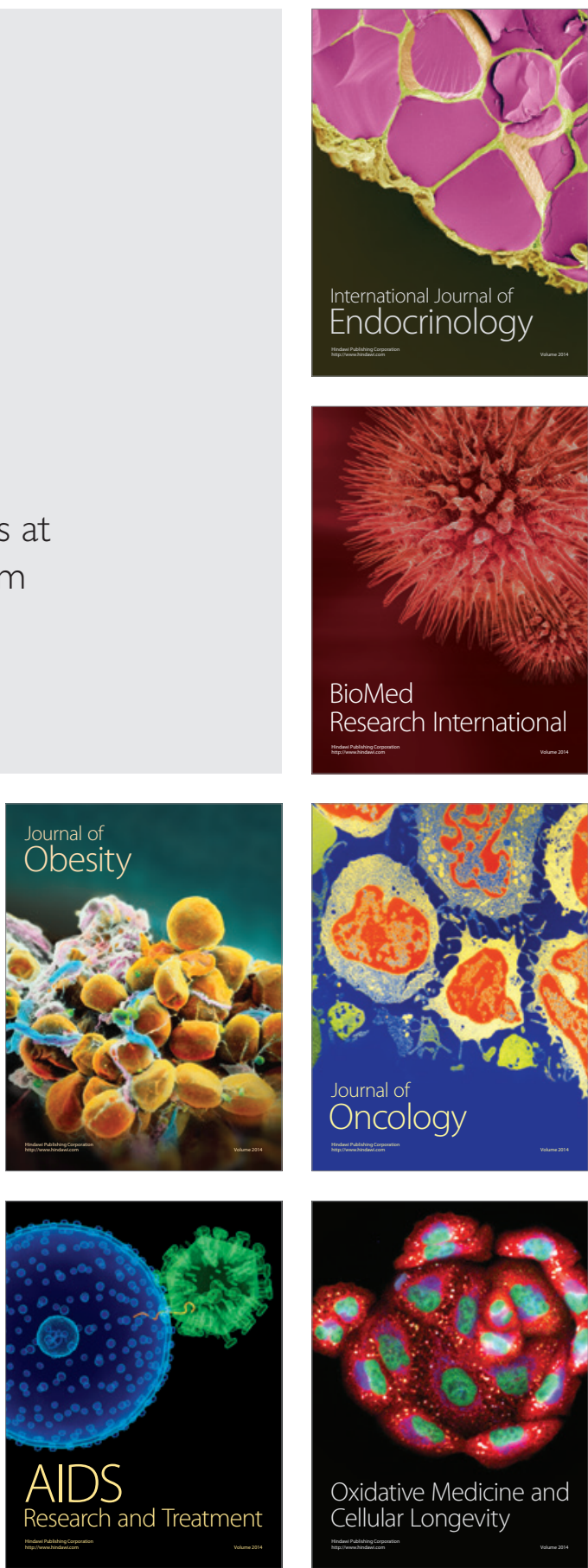